\title{
A new approach to ferrocene derived alkenes via copper- catalyzed olefination
}

\author{
Vasily M. Muzalevskiy ${ }^{1}$, Aleksei V. Shastin ${ }^{1,2}$, Alexandra D. Demidovich ${ }^{1}$, \\ Namiq G. Shikhaliev ${ }^{3}$, Abel M. Magerramov ${ }^{3}$, Victor N. Khrustalev ${ }^{4,5}$, \\ Rustem D. Rakhimov ${ }^{1}$, Sergey Z. Vatsadze ${ }^{1}$ and Valentine G. Nenajdenko ${ }^{* 1,5}$
}

\section{Full Research Paper}

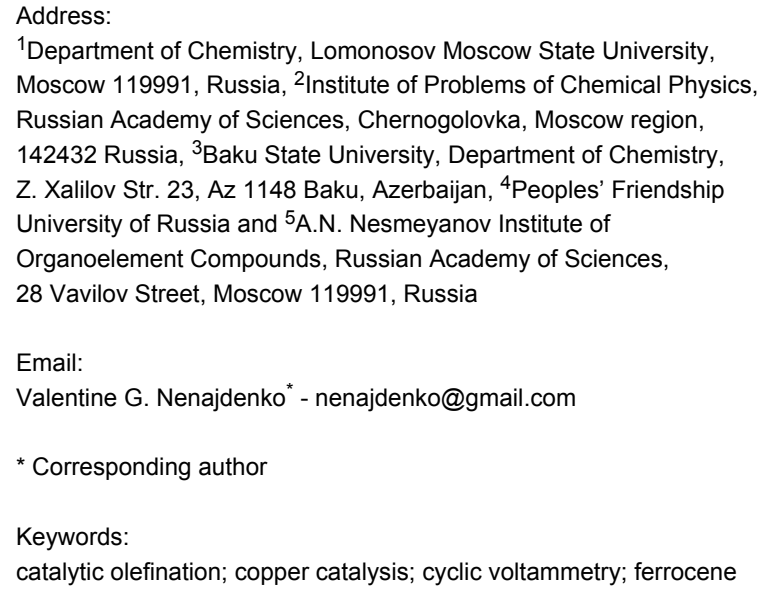

${ }^{1}$ Department of Chemistry, Lomonosov Moscow State University, Moscow 119991, Russia, ${ }^{2}$ Institute of Problems of Chemical Physics, Russian Academy of Sciences, Chernogolovka, Moscow region, 142432 Russia, ${ }^{3}$ Baku State University, Department of Chemistry, Z. Xalilov Str. 23, Az 1148 Baku, Azerbaijan, ${ }^{4}$ Peoples' Friendship University of Russia and ${ }^{5}$ A.N. Nesmeyanov Institute of Organoelement Compounds, Russian Academy of Sciences, 28 Vavilov Street, Moscow 119991, Russia

\section{Email:}

Valentine G. Nenajdenko* - nenajdenko@gmail.com

* Corresponding author

Keywords:

catalytic olefination; copper catalysis; cyclic voltammetry; ferrocene

\author{
Beilstein J. Org. Chem. 2015, 11, 2072-2078. \\ doi:10.3762/bjoc.11.223
}

Received: 10 August 2015

Accepted: 15 October 2015

Published: 03 November 2015

This article is part of the Thematic Series "Copper catalysis in organic synthesis".

Guest Editor: S. R. Chemler

(C) 2015 Muzalevskiy et al; licensee Beilstein-Institut.

License and terms: see end of document.

\begin{abstract}
A new approach to ferrocenyl haloalkenes and bis-alkenes was elaborated. The key procedure involves copper catalyzed olefination of $\mathrm{N}$-unsubstituted hydrazones, obtained from ferrocene-containing carbonyl compounds and hydrazine, with polyhaloalkanes. The procedure is simple, cheap and could be applied for the utilization of environmentally harmful polyhalocarbons. The cyclic voltammetry study of the representative examples of the synthesized ferrocenyl alkenes shows the strong dependence of the cathodic behavior on the amount of vinyl groups: while for the monoalkene containing molecules no reduction is seen, the divinyl products are reduced in several steps.
\end{abstract}

\section{Introduction}

The introduction of complex functional fragments into the specified place of the target molecule is of current interest in modern synthetic chemistry [1]. From this point of view, the development of ferrocene-based molecules as crucial fragments of new materials and novel pharmacological entities is of great importance. Indeed, since the discovery of ferrocene [2] and the synthesis of the first polymer based on vinylferrocene [3], the chemistry of ferrocene and its derivatives is developing very rapidly. Ferrocene derivatives are widely applied in industry, for example, diethylferrocene is a combustion accelerator used as additive to gasoline [4]. There are many drugs containing a ferrocene fragment in their structures (Scheme 1) [5]. The 


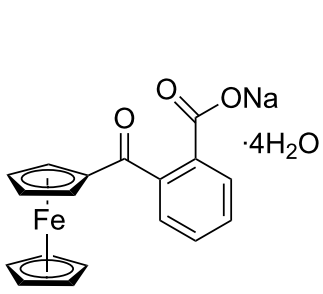

ferroceron

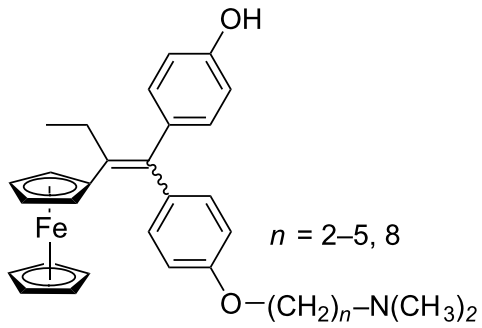

ferrocifens<smiles>CN(C)Cc1cccc(Pc2ccccc2)c1</smiles>

ferroquine

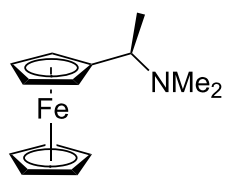

(R) Ugi's amine

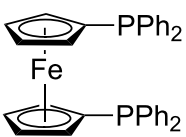

DPPF

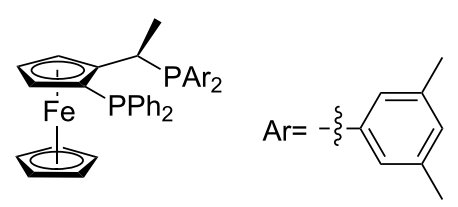

xyliphos

Scheme 1: Examples of ferrocene derived drugs and ligands.

ferrocene core is also a very popular scaffold for ligand design, particularly, in asymmetric catalysis (Scheme 1).

Probably, the most challenging application of ferrocenes is the production of ferrocene-containing polymers [6-8] (Scheme 2). The polymers have a set of unique properties and are used in various fields of science, technology and medicine (conducting and semiconducting materials [9], drugs [10], biosensors [11$13]$, liquid crystal materials $[14,15]$, coordination polymers [16], and more [10]).

Ethynylferrocenes are one of the most popular and extremely effective starting compounds in the creation of ferrocenyl polymers. They are widely used for making both polyferrocenylvinylenes (double bond linkers) [17-21] and polyethynylferrocenes (triple bond linkers) [22-25]. There are several methods for the preparation of ethynylferrocenes [24-29]. In most cases, the key reagents for the synthesis of ethynylferrocene are the corresponding mono- and dihalogenvinylferrocene derivatives. These compounds are generally prepared using a variation of the Wittig reaction (the Corey-Fuchs reaction) using a 2-4-fold molar excess of triphenylphosphine [2731].

\section{Results and Discussion Synthesis of halovinylferrocenes}

A few years ago we discovered a new reaction for a double carbon-carbon bond formation - the reaction of catalytic olefination. It was shown that the copper-catalyzed reaction of unsubstituted hydrazones of aromatic (aliphatic) aldehydes and ketones with a wide range of polyhalogenalkanes leads to the corresponding substituted ethylenes with one or two geminal halogen atoms [32-36]. In the present study, we investigated the possibility of using a catalytic olefination reaction for the synthesis of ferrocene derivatives. As a result, several well-known and previously unknown ferrocene-containing alkene compounds were obtained.

First, ferrocene carbaldehyde was investigated. It was found, that under usual conditions of the reaction (equal amount of $\mathrm{N}_{2} \mathrm{H}_{4} \cdot \mathrm{H}_{2} \mathrm{O}$, DMSO or EtOH as a solvent) the yields of the desired alkenes were not good enough. Better results were obtained in ethylene glycol with a 4-fold excess of $\mathrm{N}_{2} \mathrm{H}_{4} \cdot \mathrm{H}_{2} \mathrm{O}$ (novel media just reported for COR [37]). In this case, target alkenes were isolated in up to $62 \%$ yield. Using $\mathrm{C} 2$-freons fluorinated alkenes 3-5 were synthesized (Scheme 3). The reaction proceeds stereoselectively to give a mixture of isomers in which
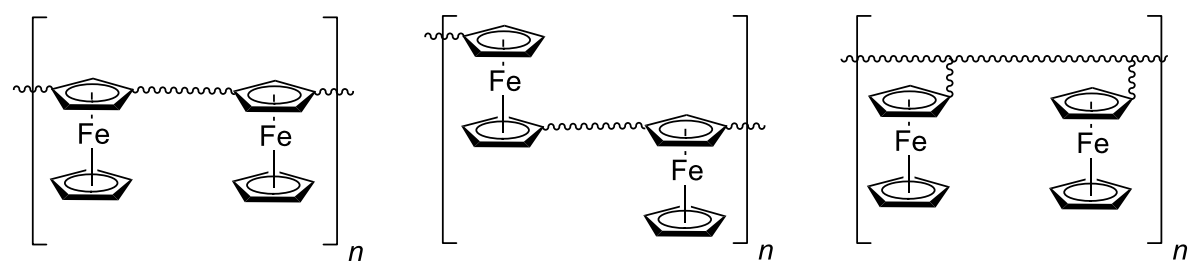


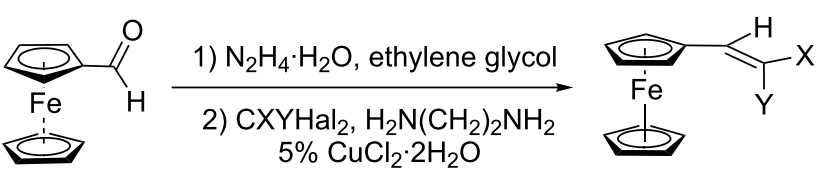

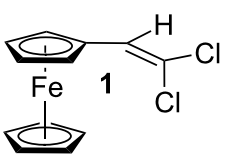

$\mathrm{CCl}_{4}, 62 \%$

$\mathrm{CBrCl}_{3}, 62 \%$

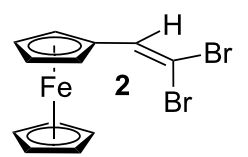

$\mathrm{CBr}_{4}, 38 \%$

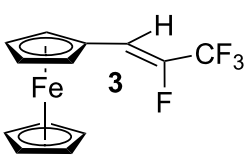

$\mathrm{CF}_{3} \mathrm{CFBr}_{2}, 46 \%$ ZIE 74:26
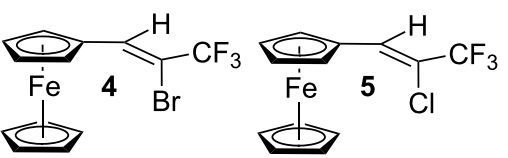

$\mathrm{CF}_{3} \mathrm{CBr}_{3}, 42 \%$ ZIE 75:25

Scheme 3: Synthesis of ferrocene-derived alkenes from ferrocene carbaldehyde.

the less hindered $Z$-isomer dominates. The assignment of the isomers was easily performed by comparison of NMR spectral data with those previously reported for the $Z, E$-isomers of similar alkenes [38-40]. The trifluoromethyl group of the $Z$-isomers of compounds $\mathbf{3}-\mathbf{5}$ resonates in higher field in ${ }^{19}$ F NMR (3: $\left.-72.8 \mathrm{ppm}, 4:-67.1 \mathrm{ppm}, \mathbf{5}:-69.0 \mathrm{ppm}\right)$ than that of the $E$-isomers (3: -67.9 ppm, 4: $-60.2 \mathrm{ppm}, \mathbf{5}:-62.4 \mathrm{ppm}$ ). In the case of compound $\mathbf{3}$ an additional conformation can be seen in the ${ }^{1} \mathrm{H}$ NMR spectrum. It is well-known, that ${ }^{2} J_{\mathrm{HF}}$ coupling constants in alkenes with relative trans-configuration of hydrogen and fluorine atoms are usually approximately twice bigger than the corresponding coupling constants in alkenes with cis-configuration. The values found in $\mathbf{3}$ are $36.5 \mathrm{~Hz}$
(Z-isomer by systematic nomenclature, but trans-configuration of $\mathrm{H}$ and $\mathrm{F}$ ) and $16.2 \mathrm{~Hz}$ ( $E$-isomer).

Acetylferrocene and 1,1'-diacetylferrocene were also involved successfully into this transformation (Scheme 4). Our preliminary study of the catalytic olefination of acetylferrocene by $\mathrm{CF}_{3} \mathrm{CBr}_{3}$ (alkene 8) and $\mathrm{CBr}_{4}$ (alkene 7) indicates, that in contrast to ferrocene carbaldehyde, better results were achieved in DMSO using previously prepared hydrazones [37]. A series of ferrocene derivatives including fluorinated ones was prepared in good yields. Unsymmetrical alkenes $\mathbf{8}$ and $\mathbf{9}$ were obtained as a mixture of isomers in approximately equal amounts. Identification of the structures of the $E$ - and $Z$-isomers
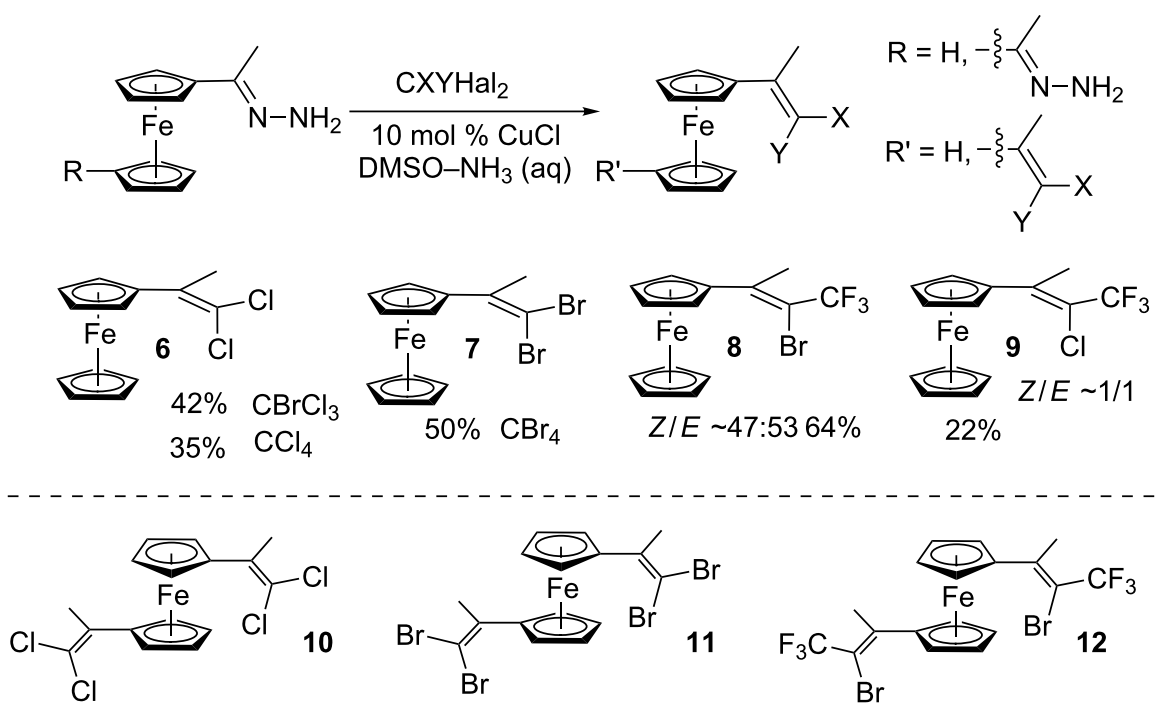

$\mathrm{CCl}_{4}, 46 \%$

$\mathrm{CBrCl}_{3}, 58 \%$

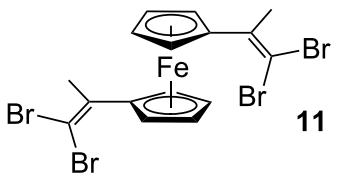

$\mathrm{CBr}_{4}, 74 \%$

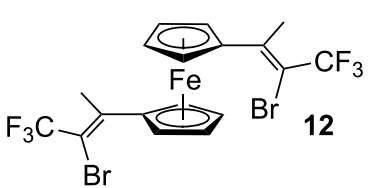

$\mathrm{CF}_{3} \mathrm{CBr}_{3}, 65 \%$

Z,Z:Z,E:E,E

25:50:25 
of alkene 8 was accurately performed by an X-ray crystallographic study using crystals of $\mathbf{8}$ obtained from ethanol solution (see Supporting Information File 1 and [41]). Due to the presence of two double bonds in alkene $\mathbf{1 2}$ the formation of three isomers $(Z, Z, Z, E$ and $E, E)$ is possible. Similar to alkenes $\mathbf{8}$ and 9 no stereoselectivity is observed to give equal numbers of cisand trans-double bonds in the obtained molecules. As a result a 25:50:25 mixture of $Z, Z, Z, E$ and $E, E$ was formed. The higher quantity of the $Z, E$-isomer is a result of statistical doubling (in fact, the reaction gives $Z, E$ and $E, Z$-alkenes which are identical)

Di- and tetrahalovinylferrocenes obtained in our work are of interest for the synthesis of ethynylferrocenes, as monomers for making ferrocene-containing polymers and as intermediates in the synthesis of ferrocene analogs of tamoxifen and other medicinally relevant molecules.

\section{Electrochemical properties of halovinyl- ferrocenes}

The ferrocene unit possesses several exciting electrochemical characteristics, such as fast electron-transfer rate, low oxidation potential, and stability of two redox states. The combination of a ferrocene and an alkene moiety in one molecule might be of interest for the synthesis of functional devises that can be exploited in electrocatalysis, electroanalysis, and biosensing applications, since the alkene fragment could be used to graft the molecule to the polymer support or to copolymerize it with the appropriate monomers. Therefore, we have also examined the electrochemical properties of the compounds obtained. It was shown that the oxidation of the ferrocene unit proceeds in accordance to the data found in literature, whereas the reduction was found only in the case of bis(halovinyl)ferrocenes. Our results clearly indicate that the anodic and cathodic electrochemical processes proceed on different parts of the molecules. While in the anodic region the changes are localized on the iron atom, the electron transfer from the cathode occurs at a double bond.

Three representative groups of halovinylferrocenes were studied using cyclic voltammetry (Table 1 ). The first group was formed from three omega-dichloro derivatives $\mathbf{1 , 6}$, and $\mathbf{1 0}$. The second one was made from three omega-dibromo products $\mathbf{2}, \mathbf{7}$, and $\mathbf{1 1}$, and the last group consisted of bromotrifluoromethyl molecules $\mathbf{4 , 8}$, and 12. Such selection allowed us to estimate the effect of the nature of substituent on the electrochemical behavior of the molecule.

All compounds are characterized by reversible oxidation waves in the range of $0.64-0.84 \mathrm{~V}$ that corresponds to the $\mathrm{Fe}^{2+} / \mathrm{Fe}^{3+}$ redox transformation. The values of the respective oxidation potential depend mainly on the amount of the vinyl groups attached to the ferrocene core. There is also the effect of the halogen atom, though to a lesser extent compared to the effect of the amount of vinyl groups. For example, all dichloro and dibromo compounds $(\mathbf{1}, \mathbf{2}, \mathbf{6}$, and $\mathbf{7}$, one vinyl fragment) are oxidized at potentials of $0.64-0.65 \mathrm{~V}$, whereas for the corresponding tetrahalo compounds (10 and $\mathbf{1 1}$, two vinyl fragments) these values are shifted to more anodic potentials, namely, $0.74 \mathrm{~V}$. The same is true for trifluoromethyl ferrocenes $\mathbf{4 , 8}$, and 12 (Figure 1).

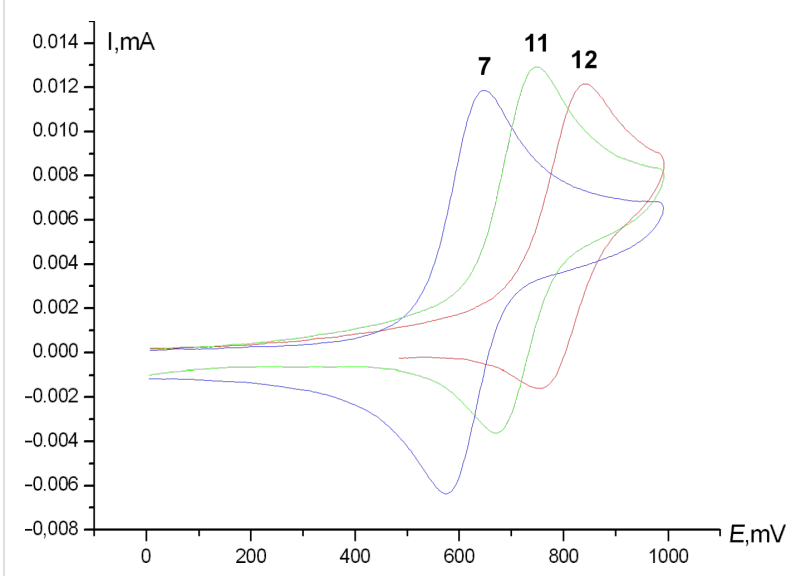

Figure 1: Typical voltammogramms of vinylferrocenes 7 (blue), 11 (green), 12 (red), anodic region.

In the cathodic region, monovinylic compounds $\mathbf{1 , 2 , 4}$, and $\mathbf{6}-\mathbf{8}$ show no reduction up to $1.80 \mathrm{~V}$, whilst the corresponding divinylic molecules 10-12 exhibit pronounced reduction waves in the range of $0.34-1.66 \mathrm{~V}$ (Figure 2).

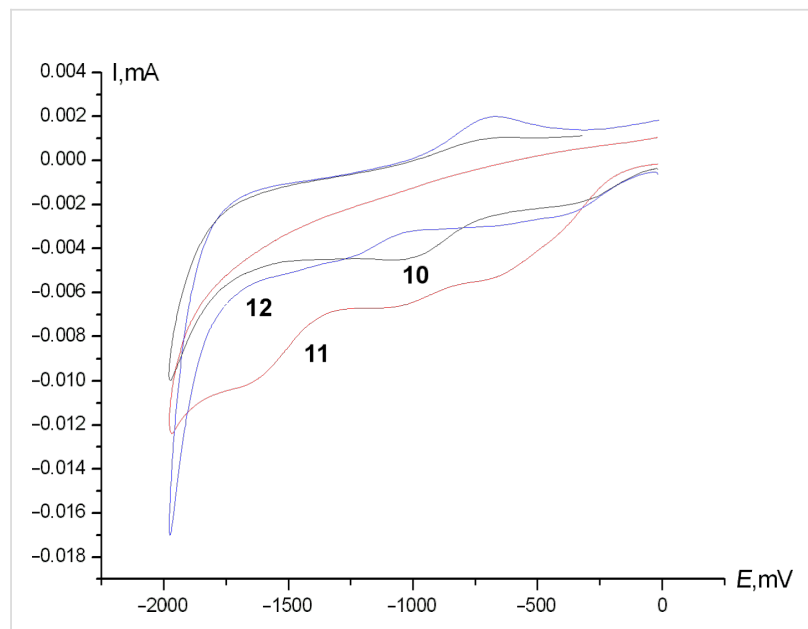

Figure 2: Typical voltammogramms of divinylferrocenes 10 (black), 11 (red), 12 (blue), cathodic region. 
Table 1: Cyclic voltammetry data for selected halovinylferrocenes. Pt electrode, DMF, $\mathrm{Ag} / \mathrm{AgCl} / \mathrm{KCl}$ (sat.), $\mathrm{Bu}_{4} \mathrm{NBF}_{4}$

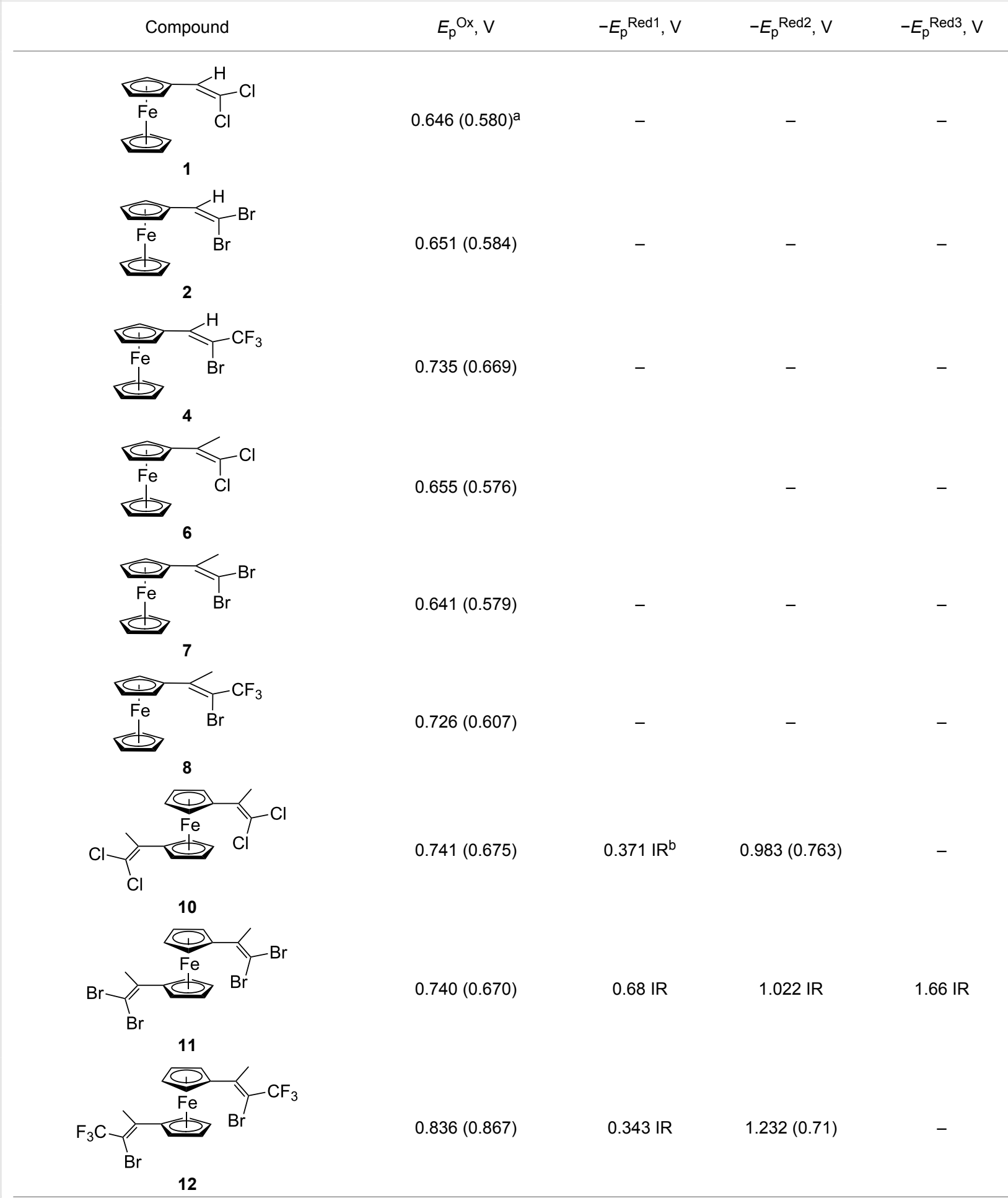

${ }^{\mathrm{a}} \mathrm{n}$ the case of a reversible peak the reverse potentials are shown in paranthesis. ${ }^{\mathrm{b}} \mathrm{R}$ means irreversible.

The processes behind the cathodic waves are not totally clear at the moment, but we assume that the radical-ions formed after the first electron transfer would enter the intramolecular cyclization reaction involving the second adjacent double bond with subsequent electropolymerization. The latter is confirmed by a pronounced decrease in current values (3-4 times) as compared to current values of oxidation at the iron atom. These findings allow us to state that the synthesized molecules are 
promising starting materials for the electrochemical synthesis of ferrocene-containing conjugated polymers.

\section{Conclusion}

In conclusion, a novel stereoselective route to ferrocenyl haloalkenes and bis-alkenes was elaborated on the basis of a catalytic olefination reaction of $\mathrm{N}$-unsubstituted hydrazones obtained from ferrocene-containing aldehydes and ketones. Electrochemical properties of synthesized alkenes were investigated and promising electrochemical characteristics were demonstrated.

\section{Supporting Information}

\section{Supporting Information File 1}

Experimental details, analytical data and copies of NMR spectra of all synthesized compounds, X-ray data of compound $\mathbf{8}$.

[http://www.beilstein-journals.org/bjoc/content/ supplementary/1860-5397-11-223-S1.pdf]

\section{Acknowledgements}

This work was supported by the Russian Foundation for the Basic Research (Grants no 13-03-01129-a and 14-03-91160GFEN, investigation of electrochemical properties of halovinylferrocenes) and the Russian Science Foundation (grant no. 14-13-00083, synthesis of starting materials and halovinylferrocenes). The authors acknowledge partial support in measuring of NMR from the M.V. Lomonosov Moscow State University Program of Development.

\section{References}

1. Ananikov, V. P.; Khemchyan, L. L.; Ivanova, Yu. V.; Bukhtiyarov, V. I.; Sorokin, A. M.; Prosvirin, I. P.; Vatsadze, S. Z.; Medved'ko, A. V.; Nuriev, V. N.; Dilman, A. D.; Levin, V. V.; Koptyug, I. V.; Kovtunov, K. V.; Zhivonitko, V. V.; Likholobov, V. A.; Romanenko, A. V.; Simonov, P. A.; Nenajdenko, V. G.; Shmatova, O. I.; Muzalevskiy, V. M.; Nechaev, M. S.; Asachenko, A. F.; Morozov, O. S.; Dzhevakov, P. B.; Osipov, S. N.; Vorobyeva, D. V.; Topchiy, M. A.; Zotova, M. A.; Ponomarenko, S. A.; Borshchev, O. V.; Luponosov, Yu. N.; Rempel, A. A.; Valeeva, A. A.; Stakheev, A. Yu.; Turova, O. V.; Mashkovsky, I. S.; Sysolyatin, S. V.; Malykhin, V. V.; Bukhtiyarova, G. A.; Terent'ev, A. O.; Krylov, I. B. Russ. Chem. Rev. 2014, 83, 885-985. doi:10.1070/RC2014v83n10ABEH004471

2. Kealy, T. J.; Pauson, P. L. Nature 1951, 168, 1039-1040. doi:10.1038/1681039b0

3. Arimoto, F. S.; Haven, A. C., Jr. J. Am. Chem. Soc. 1955, 77, 6295-6297. doi:10.1021/ja01628a068

4. Tong, R.; Zhao, Y.; Wang, L.; Yu, H.; Ren, F.; Saleem, M.; Amer, W. A. J. Organomet. Chem. 2014, 755, 16-32. doi:10.1016/j.jorganchem.2013.12.052
5. Braga, S. S.; Silva, A. M. S. Organometallics 2013, 32, 5626-5639. doi:10.1021/om400446y

6. Wang, L.; Haogie, Y. Synthesis, Properties and Application of Ferrocenyl Polymers; Zheijang University Press, 2013.

7. Hardy, C. G.; Ren, L.; Zhang, J.; Tang, C. Isr. J. Chem. 2012, 52, 230-245. doi:10.1002/ijch.201100110

8. Heo, R. W.; Lee, T. R. J. Organomet. Chem. 1999, 578, 31-42. doi:10.1016/S0022-328X(98)01126-7

9. Deng, W.; Yamaguchi, H.; Takashima, Y.; Harada, A. Angew. Chem. 2007, 119, 5236-5239. doi:10.1002/ange.200701272

10. Neuse, E. W. J. Inorg. Organomet. Polym. Mater. 2005, 15, 3-31. doi:10.1007/s10904-004-2371-9

11. Amer, W. A.; Wang, L.; Amin, A. M.; Ma, L.; Yu, H. J. Inorg. Organomet. Polym. Mater. 2010, 20, 605-615. doi:10.1007/s10904-010-9373-6

12. Takahashi, S.; Anzai, J. Materials 2013, 6, 5742-5762. doi:10.3390/ma6125742

13. Gracia, R.; Mecerreyes, D. Polym. Chem. 2013, 4, 2206-2214. doi:10.1039/c3py21118e

14. Gao, Y.; Shreeve, J. M. J. Inorg. Organomet. Polym. Mater. 2007, 17, 19-36. doi:10.1007/s10904-006-9095-y

15. Kadkin, O. N.; Galyametdinov, Yu. G. Russ. Chem. Rev. 2012, 81, 675-699. doi:10.1070/RC2012v081n08ABEH004270

16. Horikoshi, R.; Mochida, T. Eur. J. Inorg. Chem. 2010, 5355-5371. doi:10.1002/ejic.201000525

17. Dragutan, I.; Dragutan, V.; Fischer, H. J. Inorg. Organomet. Polym. Mater. 2008, 18, 311-324. doi:10.1007/s10904-008-9213-0

18. Buchmeiser, M.; Schrock, R. R. Macromolecules 1995, 28, 6642-6649. doi:10.1021/ma00123a034

19. Buchmeiser, M. R. Macromolecules 1997, 30, 2274-2277. doi:10.1021/ma961317f

20. Buchmeiser, M. R.; Schuler, N.; Kaltenhauser, G.; Ongania, K.-H.; Lagoja, I.; Wurst, K.; Schottenberger, H. Macromolecules 1998, 31, 3175-3183. doi:10.1021/ma9716948

21. Camus, A.; Faruffini, V.; Furlani, A.; Marsich, N.; Ortaggi, G.; Paolesse, R.; Russo, M. V. Appl. Organomet. Chem. 1988, 2, 533-537. doi:10.1002/aoc.590020606

22. Hudson, R. D. A. J. Organomet. Chem. 2001, 637-639, 47-69. doi:10.1016/S0022-328X(01)01142-1

23. Abd-El-Aziz, A. S. Macromol. Rapid Commun. 2002, 23, 995-1031. doi:10.1002/marc.200290003

24. Butler, I. R.; Boyes, A. L.; Kelly, G.; Quayle, S. C.; Herzig, T.; Szewczyk, J. Inorg. Chem. Commun. 1999, 2, 403-406. doi:10.1016/S1387-7003(99)00099-4

25. Plenio, H.; Hermann, J.; Sehring, A. Chem. - Eur. J. 2000, 6, 1820-1829.

doi:10.1002/(SICI)1521-3765(20000515)6:10<1820::AID-CHEM1820> 3.0.CO;2-A

26. Schloegl, K.; Egger, H. Monatsh. Chem. 1963, 94, 376-392.

27. Luo, S.-J.; Liu, Y.-H.; Liu, C.-M.; Liang, Y.-M.; Ma, Y.-X. Synth. Commun. 2000, 30, 1569-1572. doi:10.1080/00397910008087190

28. Clément, S.; Guyard, L.; Knorr, M.; Dilsky, S.; Strohmann, C.; Arroyo, M. J. Organomet. Chem. 2007, 692, 839-850. doi:10.1016/j.jorganchem.2006.10.039

29. Pedersen, B.; Wagner, G.; Herrmann, R.; Scherer, W.; Meerholz, K.; Schmälzlin, E.; Bräuchle, C. J. Organomet. Chem. 1999, 590, 129-137. doi:10.1016/S0022-328X(99)00440-4 
30. Tsuboya, N.; Hamasaki, R.; Ito, M.; Mitsuishi, M.; Miyashita, T.; Yamamoto, Y. J. Mater. Chem. 2003, 13, 511-513.

doi:10.1039/b211019a

31. Clément, S.; Guyard, L.; Knorr, M.; Gessner, V. H.; Strohmann, C. Acta Crystallogr., Sect. E 2009, 65, m334.

doi:10.1107/S1600536809006102

32. Shastin, A. V.; Korotchenko, V. N.; Nenaidenko, V. G.;

Balenkova, E. S. Russ. Chem. Bull. 1999, 48, 2184-2185.

doi:10.1007/BF02494876

33. Shastin, A. V.; Korotchenko, V. N.; Nenajdenko, V. G.; Balenkova, E. S. Tetrahedron 2000, 56, 6557-6563.

doi:10.1016/S0040-4020(00)00606-2

34. Nenajdenko, V. G.; Varseev, G. N.; Korotchenko, V. N.; Shastin, A. V.; Balenkova, E. S. J. Fluorine Chem. 2003, 124, 115-118.

doi:10.1016/S0022-1139(03)00199-4

35. Shastin, A. V.; Muzalevsky, V. M.; Balenkova, E. S.; Nenajdenko, V. G. Mendeleev Commun. 2006, 16, 179-180.

doi:10.1070/MC2006v016n03ABEH002282

36. Muzalevskiy, V. M.; Shikhaliev, N. G.; Magerramov, A. M.;

Gurbanova, N. V.; Geydarova, S. D.; Balenkova, E. S.; Shastin, A. V.; Nenajdenko, V. G. Russ. Chem. Bull. 2013, 62, 678-682. doi:10.1007/s11172-013-0091-4

37. Hirotaki, K.; Kawazoe, G.; Hanamoto, T. J. Fluorine Chem. 2015, 171, 169-173. doi:10.1016/j.jluchem.2014.07.018

38. Nenajdenko, V. G.; Varseev, G. N.; Korotchenko, V. N.; Shastin, A. V.; Balenkova, E. S. J. Fluorine Chem. 2004, 125, 1339-1345.

doi:10.1016/j.jluchem.2004.04.002

39. Nenajdenko, V. G.; Varseev, G. N.; Shastin, A. V.; Balenkova, E. S. J. Fluorine Chem. 2005, 126, 907-913.

doi:10.1016/j.jluchem.2005.03.020

40. Korotchenko, V. N.; Shastin, A. V.; Nenajdenko, V. G.; Balenkova, E. S. Tetrahedron 2001, 57, 7519-7527. doi:10.1016/S0040-4020(01)00701-3

41. Shixaliyev, N. G.; Heydarova, S. J.; Muzalevskiy, V. M.; Nenajdenko, V. G.; Rahimova, A. G. Azerb. Khim. Zh. 2013, 78-83.

\section{License and Terms}

This is an Open Access article under the terms of the Creative Commons Attribution License (http://creativecommons.org/licenses/by/2.0), which permits unrestricted use, distribution, and reproduction in any medium, provided the original work is properly cited.

The license is subject to the Beilstein Journal of Organic Chemistry terms and conditions:

(http://www.beilstein-journals.org/bjoc)

The definitive version of this article is the electronic one which can be found at:

$\underline{\text { doi: } 10.3762 / \text { bjoc. } 11.223}$ 